\title{
PERLINDUNGAN HUKUM TERHADAP KORBAN SEKSUAL OLEH NEGARA \\ (Studi Kasus di Pengadilan Negeri Mandailing Natal)
}

\author{
Rosmawati \\ Sekolah Tinggi Ilmu Hukum Benteng Huraba \\ rosmawatii.wati@gmail.com
}

\begin{abstract}
When the state is the only party entitled to determine which is called the violation and what is not, then the position of state law and law enforcement officials is higher than the individual and the directly harmed perpetrator inflicted. This type of research in this thesis is a normative legal research. This study aims to examine the legal arrangements concering the legal protection by the state against sexualy victimized. To assess the state legal protection for victims of sexual abuse. To examine the legal protection policy for victims of sexual. Legal arrangement reganding legal protection bythe state against sexualy victimized. Law No.23 Year 2002 on Child Protection, set up the law for victims of abuse any person knowingly to violence or threats of violence, force, deceit, a series of lies, or persuading a child to commit or tolerate obscene acts, shall be punished with imprisonment minimum of 3 years and maximum fine of Rp. At Least 300 milillion and Rp.60 milion. Law No 13 of 2006 on the Protection of Witnesses and Victims in preamble this law was born because thet one valid evidence in a court proceeding is whitness and/or victim who hear, see, or experience the occurrence of a crime in an effort to seek and find clarity about criminal offenses commetted by criminals. Legal protection by the state against sexually victimized. The issue of protection against minors who are victims of abuse or sexual assault is not an easy mather for us to practice in reality in everyday life. Particularly in the case of fedofilia or sexual abuse of children under the age where a child should not get the wrong treatment, because every child has a right contained in Law No.23 of 2002 on Child Protection Article 81 paragraph (1) and (2). The rights of children who are victims of crime are : 1) Getting physical assistance (medical first aid, cloting, shelter and so on). 2) Got a problem resolution support (reporting, legal counsel, and defense). 3) Got back his property. 4) Obtain guidance and rehabilitation. Obtaining compensation (restitution, compensation) of the perpetrator (according to ability) or other parties concered for justice and welfare are concered. Penal sanctions set out clearly the Child Protection Act. Non Penal sanctions against sexual victims, especially children are abstract, meaning is less clear how much compensation

Keywords: Normative Protection; Sexual; Law
\end{abstract}

\section{Abstrak}

Ketika Negara merupakan satu-satunya pihak yang berhak menentukan mana yang disebut pelanggaran dan mana yang tidak, maka kedudukan hukum negara dan aparat penegak hukumnya yang lebih tinggi 
dibandingkan dengan perseorangan dan korban yang dirugikan secara langsung akibat perbuatan pelaku. Jenis penelitian dalam tesis ini adalah penelitian hukum Normatif. Penelitian ini bertujuan untuk mengkaji pengaturan hukum mengenai perlindungan hukum terhadap korban seksual oleh Negara. Untuk mengkaji perlindungan hukum terhadap korban seksual. Pengaturan hukum mengenai perlindungan hukum terhadap korban seksual oleh Negara. Undang-undang Nomor 23 tahun 2002 Tentang Perlindungan anak, mengatur hukum bagi korban perbuatan "cabul setiap orang dengan sengaja melakukan kekerasan atau ancaman kekerasan, memaksa, melakukan tipu muslihat, serangkaian kebohongan, atau membujuk anak untuk melakukan atau membiarkan melakukan perbuatan cabul, dipidana dengan pidana penjara paling singkat 3 tahun dan paling lama 15 tahun dan denda paling banyak Rp.300.000.000 dan paling sedikit Rp.60.000.000. Undang-undang Nomor 13 Tahun 2006 Tentang Perlindungan Saksi dan Korban. Dalam Konsiderannya undang-undang ini lahir dikarenakan bahwa salah satu alat bukti yang sah dalam proses peradilan pidana adalah keterangan saksi dan/Korban yang mendengar, melihat, atau mengalami sendiri terjadinya suatu tindak pidana dalam upaya mencari dan menemukan kejelasan tentang tindak pidana yang dilakukan oleh pelaku tindak pidana.Perlindungan hukum terhadap korban seksual oleh Negara. Masalah perlindungan terhadap anak dibawah umur yang menjadi korban pencabulan atau kekerasan seksual bukan persoalan yang mudah untuk kita praktekkan dalam kenyataan di kehidupan sehari-hari. Khususnya dalam kasus pencabulan atau kekerasan seksual terhadap anak dibawah umur yang dimana seorang anak tidak semestinya mendapatkan perlakuan yang salah tersebut, dikarenakan setiap anak memiliki hak yang terkandung dalam undang-undang no 23 Tahun 2002 tentang perlindungan anak pasal 81 ayat (1) dan (2) . Hak-hak yang menjadi korban perbuatan kriminal adalah: 1) Mendapat bantuan Fisik (Pertolongan pertama kesehatan, pakaian, naungan dan sebagainya).2) Mendapat bantuan penyelesaian permasalahan yang (melapor, nasihat hukum, dan pembelaan).3) Mendapat kembali hak miliknya). 4)Kompensasi dari pihak pelaku (sesuai kemampuan) atau pihak lain yang bersangkutan demi keadilan dan kesejahteraan yang bersangkutan. Sanksi Penal diatur dengan jelas dengan Undang-undang Perlindungan Anak. Sanksi non penal terhadap korban seksual terutama anak masih abstrak artinya masih kurang jelas berapa ganti ruginya.

Kata Kunci: Perlindungan Normatif; Seksual; Hukum

\section{PENDAHULUAN}

Secara umum Hukum Pidana memiliki fungsi yang sama dengan bidang hukum lainnya yaitu menjaga ketertiban masyarakat sehingga kesejahteraan dan kedamaian hidup dapat diciptakan disamping keadilan sebagai cita hukum yang tertinggi. Akan tetapi khasanah ilmu pengetahuan hukum, menempatkan 
hukum pidana dalam fungsinya yang istimewa yaitu sebagai sarana terakhir atau ultimum remedium. Dalam penyelesaian perselisihan dibidang keperdataan atau administrasi, penderitaan yang dialami oleh salah satu pihak yang dinyatakan bersalah hanya merupakan pengecualian atas kewajiban yang diembankan hukum kepadanya. ${ }^{1}$

Ketika Negara merupakan satu-satunya pihak yang berhak menentukan mana yang disebut pelanggaran dan mana yang tidak, maka kedudukan hukum negara dan aparat penegak hukumnya yang lebih tinggi dibandingkan dengan perseorangan dan korban yang dirugikan secara langsung akibat perbuatan pelaku. Hanya Polisi yang berhak melakukan penuntutan dan hanya Hakim yang berhak memutus bersalah tidaknya seseorang. ${ }^{2}$ Hukum Negara dan aparat penegak hukumnya memonopoli semua pelanggaran, dan korban hanya berhak menjadi penonton, tidak boleh masuk ke dalam sistem yang dibuat dan ditentukan oleh hukum Negara. ${ }^{3}$

Demikian halnya dengan proses penyelesaian semua pelanggaran tanpa melihat karakter dari masing-masing pelanggaran itu dan kerugian yang dialami oleh korban. Ketika terjadi pelanggaran yang bersifat publik, maka negara sudah menyediakan cara bagaimana menyelesaikan pelanggaran tersebut, pelanggaran dijatuhi ketika terbukti bersalah dan hukuman yang dijatuhkan sesuai dengan ketentuan yang diatur oleh hukum negara. Singkatnya, penjatuhan hukuman oleh hukum negara bertujuan sebagai pembalasan, pencegahan, dan membuat jera, sehingga pelanggar tidak mengulang perbuatannya itu. ${ }^{4}$

Kasus tindak pidana perkosaan paling banyak menimbulkan kesulitan dalam penyelesaiaannya baik pada tahap penyidikan, penuntutan, maupun pada tahap penjatuhan putusan. Selain kesulitan dalam batasan diatas, juga kesulitan pembuktian misalnya perkosaan atau perbuatan cabul yang umumnya dilakukan tanpa kehadiran orang lain. ${ }^{5}$

Walaupun banyak tindak pidana perkosaan yang telah diproses sampai

\footnotetext{
14. hlm. 26 .

${ }^{2}$ Rusli Muhammad, Hukum acara pidana kontemporer (Bandung: Citra Aditya Bakti, 2007),

${ }^{3}$ Mudzakkir,halaman 168, dalam Mahrus Ali, Dasar-Dasar Hukum Pidana (Jakarta: Sinar Grafika, 2011), hlm. 9.

${ }^{4}$ Ali, Dasar-Dasar Hukum Pidana.

${ }^{5}$ Leden Marpaung, Kejahatan terhadap kesusilaan dan masalah prevensinya (Jakarta: Sinar Grafika, 1996), hlm. 81.
}

${ }^{1}$ Eva Achjani Zulfa, Pergeseran paradigma pemidanaan (Bandung: Lubuk Agung, 2011), hlm. 
74 | TAZKIR: Jurnal Penelitian Ilmu-ilmu Sosial dan Keislaman

Vol. 04 No. 1 Juni 2018

ke pengadilan, ${ }^{6}$ tapi dari kasus-kasus itu pelakunya tidak dijatuhi hukuman yang maksimal sesuai dengan ketentuan perundang-undangan yang tercantum dalam Kitab Undang-Undang Hukum Pidana (KUHP) BAB XIV tentang kejahatan terhadap kesusilaan (Pasal 281 s/d 296), khususnya yang mengatur tentang tindak pidana perkosaan (Pasal 285) yang menyatakan:

"Barangsiapa dengan kekerasan atau ancaman kekerasan memaksa seorang wanita bersetubuh dengan dia diluar pernikahan, diancam karena melakukan perkosaan, dengan pidana penjara paling lama dua belas tahun".

Sudarto berpendapat bahwa untuk menanggulangi kejahatan diperlukan suatu usaha yang rasional dari masyarakat, yaitu dengan cara politik criminal. Kebijakan atau upaya penanggulangan kejahatan pada hakekatnya merupakan bagian integral dari upaya perlindungan masyarakat (social defence). Oleh karena itu dapat dikatakan, bahwa tujuan utama dari politik criminal adalah "perlindungan masyarakat untuk mencapai kesejahteraan masyarakat".7

Upaya perekayasaan hukum tentang perkosaan di Indonesia kiranya merupakan momentum yang tepat karena pembangunan hukum di dalam era pembangunan jangka panjang antara lain bertujuan untuk melaksanakan penyusunan suatu sistim hukum (pidana) Nasional. Sekalipun naskah rancangan KUHP Nasional (tentang Tindak Pidana terhadap perbuatan Melanggar Kesusilaan di muka umum, BAB XVI pasal 467) sudah selesai disusun namun rancangan ketentuan sekitar tindak pidana di bidang kesusilaan (bukan jenisnya melainkan konstruksi hukumnya) masih memerlukan kajian secara khusus terutama dari sudut pendekatan Kriminologi dan Viktimologi. ${ }^{8}$

Adapun jumlah perkara kejahatan kesusilaan di Pengadilan Negeri Mandailing Natal dari tahun 2006-2011 adalah sebagai berikut :9

\footnotetext{
${ }^{6}$ Ira Dwiati, “Perlindungan Hukum Terhadap Korban Tindak Pidana Perkosaan Dalam Peradilan Pidana" (Tesis, Universitas Diponegoro, 2007), eprints.undip.ac.id/17750/1/Ira_Dwiati_Tesis.pdf.

7 Prof Dr Barda Nawawi Arief, Bunga Rampai Kebijakan Hukum Pidana (Bandung: Prenada Media, 2016), hlm. 1, https://books.google.co.id/books?id=Clc_DwAAQBAJ.

${ }^{8}$ Romli Atmasasmita, Kapita selekta hukum pidana dan kriminologi (Bandung: Mandar Maju, 1995), hlm. 109.

${ }^{9}$ Data dari Pengadilan Negeri Mandailing Natal Tahun 2012
} 
Tabel 1

Jumlah Perkara kejahatan kesusilaan dari tahun 2006-2011

\begin{tabular}{|c|c|c|}
\hline $\begin{array}{c}\mathbf{N} \\
\mathbf{0}\end{array}$ & Tahun & Jumlah \\
\hline 1 & 2006 & 9 \\
\hline 2 & 2007 & 16 \\
\hline 3 & 2008 & 17 \\
\hline 4 & 2009 & 21 \\
\hline 5 & 2010 & 15 \\
\hline 6 & 2011 & $\mathbf{1 0 5}$ \\
\hline
\end{tabular}

Sumber: Data dari Pengadilan Mandailing Natal

Melihat tingginya angka kejahatan seksual seperti yang tertera diatas, perlu dikaji bagaimana perlindungan hukum terhadap korban seksual oleh Negara. Sehingga nantinya dapat dikaji bagaimana perlindungan hukum terhadap korban seksual oleh Negara. Bagaimana sanksi hukum terhadap pelaku kekerasan seksual dan bagaimana pertimbangan hakim dalam menjatuhkan saksi terhadap pelaku tindak pidana seksual di Pengadilan Negeri Mandailing Natal.

Adapun tujuan peenlitian ini adalah:

1. Untuk mengkaji perlindungan hukum terhadap korban seksual oleh Negara.

2. Untuk mengkaji sanksi hukum terhadap pelaku kekerasan seksual.

3. Untuk mengkaji pertimbangan hakim dalam menjatuhkan sanksi terhadap pelaku tindak pidana seksual di Pengadilan Negeri Mandailing Natal.

\section{KAJIAN TEORI}

Kitab Undang-undang Hukum Acara Pidana (KUHAP) mengadopsi norma- norma yang termaktub di dalam Universal Declaration Of Human 
76 | TAZKIR: Jurnal Penelitian Ilmu-ilmu Sosial dan Keislaman

Vol. 04 No. 1 Juni 2018

Right (1945) dan Internal Convention On Civil and Political Rights sekalipun sudah banyak memberikan perlindungan dan penghormatan kepada hak tersangka atau terdakwa, belumlah mencakup upaya-upaya perlindungan kepentingan korban yang sekaligus menjadi saksi pelapor dalam suatu tindak pidana. ${ }^{10}$

Muladi berpendapat sistem peradilan pidana (Criminal justice system) sebagai suatu jaringan (network) peradilan yang menggunakan hukum pidana sebagai sarana utamanya, baik hukum pidana materil, hukum pidana formil maupun pelaksanaan pidana. ${ }^{11}$ Menurut Friedman, sistim hukum (legal system) memiliki cakupan yang luas dari hukum itu sendiri. Kata "Hukum" sering hanya mengacu pada aturan dan peraturan. Padahal menurut Friedman sistim hukum membedakan antara aturan dan peraturan, struktur, serta lembaga dan proses yang ada dalam sistim itu. Bekerjanya hukum dalam suatu sistim ditentukan oleh tiga unsur, yaitu struktur hukum (legal structure), substansi hukum (legal substance), dan budaya hukum (legal culture). ${ }^{12}$

Struktur hukum (legal structure) merupakan kerangka berpikir yang memberikan defenisi dan bentuk bagi bekerjanya system yang ada dengan batasan yang telah ditentukan. Jadi struktur hukum dapat dikatakan sebagai institusi yang menjalankan penegakan hukum dengan segala proses yang ada didalamnya. Dalam system peradilan pidana (criminal justice system) struktur hukum (legal structure) yang menjalankan proses peradilan pidana adalah kepolisian, kejaksaan, kehakiman, dan lembaga pemasyarakatan. ${ }^{13}$

Substansi hukum (legal substance) merupakan aturan, norma dan pola perilaku manusia yang berada didalam system hukum. Substansi hukum (legal substance) berarti produk yang dihasilkan oleh orang yang berada di dalam system hukum itu, baik berupa keputusan yang telah dikeluarkan maupun aturan-aturan baru yang akan disusun. Substansi hukum (legal substance)

${ }^{10}$ Republik Indonesia dan Kepolisian Republik Indonesia, Pedoman untuk Penyidikan dan Penuntutan Tindak Pidana Traffiking dan Perlindungan Terhadap Korban Selama Proses penegakan Hukum (Jakarta: International Organization for Migrations Mission In Indonesia dan NZAID, 2005), hlm. 12.

${ }^{11}$ Mahmud Mulyadi, Modul Perkuliahan Semester Ganjil ( III ) Tahun Akademik 2007/2008, Pasca Sarjana USU, Medan, hlm. 42.

${ }^{12}$ Laurence Friedman ( 1984 ), American Law an Introduction. New York: W.W.Northon \& Company, hlm 4; Dikutip dari Marlina, Peradilan Pidana Anak di Inonesia, Pengembangan Konsep Diversi dan Restorative Justice (Bandung: PT.Refika Aditama, 2009), hlm. 14.

${ }^{13}$ Marlina, Peradilan Pidana Anak di Inonesia, Pengembangan ..., hlm. 14. 
tidak hanya pada hukum yang tertulis (law in the book), tetapi juga mencakup hukum yang hidup di masyarakat (the living law). Budaya hukum (legal culture) merupakan sikap manusia terhadap hukum dan system hukum. Sikap masyarakat ini meliputi kepercayaan, nilai-nilai, ide-ide serta harapan masyarakat terhadap hukum dan system hukum. Budaya hukum juga merupakan kekuatan social yang menentukan bagaimana hukum disalahgunakan.

Budaya hukum (legal culture) mempunyai peranan yang besar dalam system hukum (legal system) akan kehilangan kekuatannya, seperti ikan mati yang terdampar di keranjangnya, bukan ikan hidup yang berenang di lautan (without legal culture, the legal culture, the legal system is meet-as dead fish in a basket, not a living fish swimming in its sea). ${ }^{14}$

Ada beberapa teori tujuan hukum, yaitu ${ }^{15}$ :

a. Teori tujuan hukum barat atau disebut juga Grand Westem Theory, yang terdiri dari :

Teori Etis: Tujuan hukum semata-mata untuk mewujudkan keadilan (Justice).

Teori Utilistis: Tujuan hukum semata-mata untuk mewujudkan kemanfaatan (Utility).

Teori Legalistik: Tujuan hukum semat-mata untuk mewujudkan kepastian hukum (illegal certainty).

b. Teori Modern :

Teori Prioritas Baku: Tujuan hukum mencakupi keadilan, kemanfaatan dan kepastian hukum.

Teori Prioritas Kasuistik: Tujuan hukum mencakupi keadilan kemanfaatan - kepastian hukum, dengan urutan prioritas, secara proporsional, sesuai dengan kasus yang dihadapi dan ingin dipecahkan.

Ada beberapa istilah yang muncul dalam penelitian ini sehingga perlu dibuat defenisi konsep tersebut agar makna variable yang diterapkan dalam topik ini tidak menimbulkan perbedaan penafsiran.

1. Pengertian perlindungan hukum adalah suatu perlindungan yang

${ }^{14}$ Marlina, Peradilan Pidana Anak di Inonesia, Pengembangan ... hlm. 14.

15 Prof Dr Achmad Ali, Menguak Teori Hukum \& Teori Peradilan dan Teori Peradilan (Judicialprudence), Termasuk Interpretasi Undang-Undang (Legisprudence) (Jakarta: Kencana Prenada, 2009), hlm. 212-213, https://books.google.co.id/books?id=NBZNDwAAQBAJ. 
78 | TAZKIR: Jurnal Penelitian Ilmu-ilmu Sosial dan Keislaman

Vol. 04 No. 1 Juni 2018

diberikan terhadap subyek hukum dalam bentuk perangkat hukum baik yang bersifat preventif maupun yang bersifat represif, baik yang tertulis maupun tidak tertulis, dengan kata lain perlindungan hukum sebagai suatu gambaran dari fungsi hukum, yaitu konsep dimana hukum dapat memberikan suatu keadilan, ketertiban, kepastian, kemanfaatan, dan kedamaian.

2. Pengertian Hukum menurut Hans wehr kata hukum berasal dari bahas Arab, asal katanya"Hukum", yang berarti putusan (Judgement, verdice, decisison) ketetapan (provisison), perintah (command), pemerintahan (government) dan kekuasaan (authority, power). Menurut VINOGRADOFF hukum adalah seperangkat aturan yang diadakan dan dilaksanakan oleh suatu masyarakat dengan menghormati kebijakan dan pelaksanaan kekuasaan atas setiap manusia dan barang. ${ }^{16}$

3. Menurut Abdul manan hukum adalah suatu rangkaian peraturan yang menguasai tingkah laku dan peraturan tertentu dari manusia dalam hidup bermasyarakat. Hukum itu mempunyai cirri yang tetap yakni hukum merupakan suatu organ peraturan-peraturan abstrak, hukum untuk mengatur kepentingan- kepentingan manusia, siapa saja yang melanggar hukum akan dikenakan sanksi sesuai dengan apa yang telah ditentukan. ${ }^{17}$

4. Sedangkan Bellefroid mengemukakan bahwa hukum adalah segala aturan yang berlaku dalam masyarakat, mengatur tata tertib masyarakat dan didasarkan atas kekuasaan yang ada di dalam masyarakat itu. Menurut Oxford English Dictionory disebutkan bahwa hukum itu adalah kumpulan aturan, perundang- undangan atau hukum kebiasaan di dalam suatu Negara atau masyarakat mengakuinya sebagai suatu yang mempunyai kekuatan mengikat terhadap warganya. (Laws is the body of rules, whether formally erected or custumory, which a state of community recognizes as binding on its members of subjects. ${ }^{18}$

${ }^{16}$ Abdul Manan, Aspek-aspek pengubah hukum (Jakarta: Kencana, 2012), hlm. 1.

${ }^{17}$ Manan, Aspek-aspek ..., hlm. 2.

${ }^{18}$ Manan, Aspek-aspek ..., hlm. 2. 
5. Menurut Kamus Crime Dictionary yang dikutip Abdussalam. ${ }^{19}$ Bahwa victim adalah "orang yang telah mendapat penderitaan fisik atau penderitaan mental, kerugian harta benda, atau mengakibatkan mati atas perbuatan atau usaha pelanggaran ringan dilakukan oleh pelaku tindak pidana dan lainnya". Disini jelas yang dimaksud "orang yang mendapat penderitaan Fisik dan seterusnya" itu adalah korban dari pelanggaran atau tindak pidana.

6. Selaras dengan pendapat diatas Arif Gosita, ${ }^{20}$ menyatakan yang dimaksud dengan korban adalah" mereka yang menderita jasmaniah dan rohaniah sebagai akibat tindakan orang lain yang mencari pemenuhan diri sendiri atau orang lain yang bertentangan dengan kepentingan dan hak asasi yang menderita". Ini menggunakan istilah penderitaan jasmani dan rohaniah (Fisik dan mental) dari korban dan juga bertentangan dengan hak asasi manusia dari korban.

7. Selanjutnya secara yuridis pengertian korban termaktub dalam undang-undang No.13 Tahun 2006 tentang Perlindungan Saksi dan Korban, yang dinyatakan bahwa korban adalah "seseorang yang mengalami penderitaan fisik, mental, dan atau kerugian ekonomi yang diakibatkan oleh suatu tindak pidana". Melihat rumusan tersebut, yang disebut korban adalah :
a. Setiap orang.
b. Mengalami penderitaan fisik, mental, dan/atau,
c. Kerugian ekonomi.
d. Akibat tindak pidana.

8. Ternyata pengertian korban disesuaikan dengan masalah yang diatur dalam beberapa perundang-undangan tersebut. Jadi tidak ada satu pengertian yang baku, namun hakikatnya adalah sama, yaitu sebagai korban tindak pidana. Tentunya tergantung sebagai korban tindak pidana apa, misalnya kekerasan dalam rumah tangga, pelanggaran HAM yang berat dan sebagainya. Untuk pengertian umum dari korban seperti tertuang dalam undang-undang No.13 Tahun 2006.

9. Menurut Peraturan No.2 Tahun 2002 tentang Tata Cara perlindungan

\footnotetext{
${ }^{19}$ Abdussalam, Victimology (Jakarta: PT IK, 2010), hlm. 5.

${ }^{20}$ Arif Gosita, Masalah perlindungan anak (Jakarta: Akademika Presindo, 1989), hlm. 75.
} 
80 | TAZKIR: Jurnal Penelitian Ilmu-ilmu Sosial dan Keislaman

Vol. 04 No. 1 Juni 2018

terhadap korban dan saksi-saksi dalam pelanggaran HAM yang berat, korban adalah "orang perseorangan atau kelompok orang yang mengalami penderitaan sebagai akibat pelanggaran Hak Asasi Manusia yang berat yang memerlukan perlindungan fisik dan mental dari ancaman, gangguan, teror dan kekerasan pihak manapun".

\section{METODE PENELITIAN}

Jenis penelitian ini adalah penelitian hukum normative, penelitian hukum normatif meliputi penelitian terhadap asas-asas hukum seperti misalnya penelitian terhadap kaedah-kaedah hukum yang hidup didalam masyarakat. Berdasarkan pada masalah yang diutarakan sebelumnya diatas, maka metode pendekatan yang digunakan dalam penelitian ini adalah metode yuridis normative yang didukung oleh yuridis empiris untk mendapatkan data primer, dimulai dengan cara menganalisa peraturan-peraturan tentang tindak pidana seksual dalam hubungannya dengan perlindungan hukum terhadap korban seksual untuk memperoleh data sekunder. Pemilihan lokasi penelitian ini dilakukan di Pengadilan Negeri Mandailing Natal, didasarkan pada bahwasanya pengadilan yang sering menangani perkara tindak pidana seksual. Adapun populasi adalah seluruh kasus seksual di Pengadilan Negeri Mandailing Natal dan sampel dari penelitian ini adalah 1 (satu) putusan perkara tindak pidana seksual. Data dalam penelitian ini diperoleh dengan mengumpulkan data sekunder dan data primer yaitu studi kepustakaan dan wawancara.

Langkah-langkah yang ditempuh dalam penelitian ini terdiri dari 2 (Dua) tahapan meliputi :

1) Tahapan penelitian lapangan, sebagai langkah awal dilakukan dengan penentuan responden dan pengumpulan data primer. Pengumpulan data primer dengan cara wawancara berdasarkan pedoman wawancara yang telah disusun dan disiapkan sebelumnya. Kemudian dilakukan juga pengumpulan data sekunder yang ada pada lembaga hukum yang berkaitan dengan penelitian ini.

2) Tahapan penelitian kepustakaan, penelitian ini dilakukan untuk memperoleh data skunder yang meliputi bahan hukum primer, bahan hukum skunder, dan bahan hukum tertier. Data yang diperoleh 
digunakan sebagai dasar teori untuk menganalisis data primer yang diperoleh dari penelitian lapangan.

Analisis data dilakukan dengan model analisis kualitatif.

\section{HASIL PENELITIAN DAN PEMBAHASAN}

Perlindungan Hukum Bagi Korban Seksual berdasarkan Undang-undang No.23 Tahun 2002.

Dalam Undang-undang No 23 Tahun 2002 tentang Perlindungan Anak, Bab XII mengenai Ketentuan pidana, dalam pasal 82 Undang-undang Perlindungan Anak tersebut dirumuskan bahwa perbuatan cabul adalah "Setiap orang dengan sengaja melakukan kekerasan atau ancaman kekerasan, memaksa, melakukan tipu muslihat, serangkaian kebohongan, atau membujuk anak untuk melakukan atau membiarkan dilakukan perbuatan Cabul", dipidana dengan pidana penjara paling singkat 3 tahun dan paling lama 15 tahun dan denda paling banyak Rp.300.000.000 dan paling sedikit Rp.60.000.000.

Namun selanjutnya dalam perkembangannya di dalam masyarakat pasal 292 tersebut apabila menjadi acuan tunggal dalam setiap Putusan Hakim Pengadilan, maka akan banyak sekali kasus-kasus cabul yang tidak dapat dijangkau oleh pasal tersebut, oleh karena Undang-undang No.23 tahun 2002 bisa dijadikan acuan bagi Para Hakim untuk memutuskan perkara yang tidak dapat dijangkau dengan hanya mengandalkan pasal 292 KUHP. Oleh karena itu dalam penerapannya di Pengadilan dalam memberikan Putusan-putusan mengenai Tindak Pidana Pencabulan maka Para Hakim seharusnya tidak hanya terpaku kepada KUHP saja melainkan Undang-undang yang sesuai dengan kasus yang sedang disidangkan, seperti Undang-undang No.23 tahun 2002 tentang Perlindungan Anak. Sehingga eksistensi pasal 292 KUHP menjadi tidak diragukan lagi dalam memberikan efek jera kepada para pelaku tindak pidana pencabulan tersebut. Perlindungan Anak adalah segala kegiatan untuk menjamin dan melindungi anak dan hak-haknya agar dapat hidup, tumbuh, berkembang dan berpartisipasi secara optimal sesuai dengan harkat dan martabat kemanusiaan, serta mendapat perlindungan dari kekerasan dan diskriminasi (Undang-undang No.23 tahun 2002, pasal 1 butir 1).

Di Indonesia beberapa peraturan perundang-undangan yang memberikan Perlindungan Anak adalah : 
82 | TAZKIR: Jurnal Penelitian Ilmu-ilmu Sosial dan Keislaman

Vol. 04 No. 1 Juni 2018

1. Undang-undang No.23 Tahun 2002 tentang Perlindungan Anak yang disahkan tanggal 22 Oktober Tahun 2002 Undang-undang ini meletakkan kewajiban memberikan perlindungan kepada anak berdasarkan asas :

a. Non Diskriminasi.

b. Kepentingan yang terbaik bagi anak.

c. Hak untuk hidup, kelangsungan hidup, dan perkembangan.

d. Penghargaan terhadap pendapat Anak.

2. Undang-undang No.4 Tahun 1979 tentang Kesejahteraan Anak. Undangundang ini memberi Perlindungan kepada anak-anak yang tidak mampu, anak-anak terlantar, anak-anak yang mengalami masalah kelakuan, anakanak yang cacat rohani dan jasmani.

3. Undang-undang No.7 Tahun 1984 tentang Penghapusan Segala Bentuk Diskriminasi terhadap Perempuan.

Undang-undang ini memuat hak dan kewajiban Wanita berdasarkan persamaan Pria dan menyatakan pemerintah akan mengambil langkahlangkah untuk menjamin pelaksanaan Penghapusan Diskriminasi terhadap Perempuan.

4. Undang-undang No.3 Tahun 1997 tentang Pengadilan Anak.

Undang-undang ini membedakan perlakuan didalam Hukum Acara dan Ancaman Pidana terhadap Anak. Sanksi terhadap Anak, yaitu bagi anak yang berusia 8 tahun samapai 12 tahun hanya dikenakan tindakan, seperti dikembalikan kepada orang tuanya, ditempatkan pada Organisasi Sosial, dan diserahkan kepada Negara, sedangkan terhadap Anak yang sudah mencapai umur 12 sampai 18 tahun dijatuhkan pidana Perbedaan perlakuan tersebut didasarkan atas pertumbuhan dan perkembangan Fisik, mental, dan Sosial Anak.

5. Undang-undang No.4 Tahun 1997 tentang Penyandang Cacat.

Undang-undang ini kesempatan untuk mendapatkan kesamaan kedudukan, hak dan kewajiban bagi penyandang cacat dengan kesamaan kesempatan tersebut diharapkan pada penyandang cacat dapat melaksanakan fungsi sosialnya dalam arti mampu berintegrasi melalui komunikasi dan interaksi secara wajar dalam kehidupan bermasyarakat.

6. Undang-undang No.20 tentang Pengesahan ILO Convention No.138 Concerning Minimum Age For Admission to Employment. 
7. Undang-undang No.39 Tahun 1999 tentang Hak Asasi Manusia.

8. Udang-undang No.1 Tahun 2000 tentang Pengesahan ILO Convension No.182.

Dalam Undang-undang No.23 tahun 2002 tentang Perlindungan Anak, kejahatan terhadap anak yang harus dilindungi dari prilaku menyimpang seperti Pelecehan Seksual juga telah diatur dengan tegas, yaitu pasal 80 sebagai berikut:

1) Setiap orang yang melakukan kekejaman, kekerasan dan ancaman kekerasan atau penganiyaan terhadap anak dipidana dengan pidana penjara paling lama 3 tahun 6 bulan atau denda paling banyak Rp.72.000.000 (tujuh puluh dua juta rupiah).

2) Dalam hal anak sebagaimana yang dimaksud dalam ayat (1), luka berat, maka pelaku pidana dengan pidana penjara paling lama 5 Tahun atau denda paling banyak Rp.100.000.000 (seratus juta rupiah).

3) Dalam hal anak sebagaimana dimaksud dalam ayat (2) mati, maka pelaku dipidana dengan pidana penjara paling lama 10 tahun atau denda paling banyak Rp.200.000.000 (dua ratus juta rupiah).

Adapun pasal lainnya adalah dalam pasal 81 yaitu :

1. Setiap orang yang sengaja melakukan kekerasan dan ancaman kekerasan memaksa anak untuk melakukan persetubuhan dengannya atau dengan orang lain, dipidana penjara paling laam 15 tahun dan sesingkatnya 3 tahun dan denda yang paling banyak Rp.300.000.000 (tiga ratus juta rupiah) dan paling sedikit Rp.60.000.000 (enam puluh juta rupiah).

2. Ketentuan sebagaimana dimaksud dalam ayat (1) berlaku pada bagi semua orang yang dengan sengaja melakukan Tipu Muslihat, serangkaian kebohongan, atau membujuk anak melakukan dengannya atau dengan orang lain.

Dari beberapa pasal diatas maka perbuatan cabul sebagai perilaku menyimpang seksual diancam dengan ancaman hukuman yang lebih berat daripada yang diatur dalam kitab Undang-undang Hukum Pidana walaupun jenis-jenisnya secara fisik tidak disebutkan dalam ketentuan ini, akan tetapi dari rumusan pasal tersebut dapat dilihat bahwa perbuatan cabul itu dapat dilakukan terhadap anak dibawah umur dengan cara kekerasan, memaksa 
84 | TAZKIR: Jurnal Penelitian Ilmu-ilmu Sosial dan Keislaman

Vol. 04 No. 1 Juni 2018

melakukan tipu muslihat serangkaian kebohongan atau membujuk anak untuk melakukan perbuatan cabul.

\section{Undang-undang No.13 tahun 2006 tentang Perlindungan Saksi dan Korban}

Di dalam Konsiderannya, undang undang ini lahir dikarenakan bahwa salah satu alat bukti yang sah dalam proses peradilan pidana adalah keterangan saksi dan/korban yang mendengar, melihat, atau mengalami sendiri terjadinya suatu tindak pidana dalam upaya mencari dan menemukan kejelasan tentang tindak Pidana yang dilakukan oleh pelaku tindak pidana.

Penegak Hukum dalam mencari dan menemukan kejelasan tentang tindak pidana yang dilakukan oleh pelaku tindak pidana sering mengalami kesulitan karena tidak dapat menghadirkan Saksi dan/atau korban disebabkan adanya ancaman, baik fisik maupun Fisikis dari pihak tertentu. Sehubungan dengan hal tersebut, perlu dilakukan perlindungan bagi saksi dan/atau korban yang sangat penting keberadaannya dalam proses peradilan pidana.

Adapun hal-hal yang penting di dalam Undang-undang ini diatur di dalam pasal 2 yaitu: Undang-undang ini memberikan perlindungan pada saksi dan korban dalam semua tahap proses peradilan pidana dalam lingkungan peradilan. Ketentuan diatas menunjukkan bahwasanya perlindungan saksi dan korban sangat dilindungi di undang-undang ini dan Asas kepastian, kemanfaatan dan keadilan ada di dalam undang-undang ini.

Selanjutnya diatur pula mengenai asas dalam undang-undang ini yang diatur dalam pasal 3 yaitu, Perlindungan Saksi dan Korban berasaskan pada a) Penghargaan Saksi atas harkat dan Martabat manusia, b) Rasa aman, c) Keadilan, d) Tidak Diskrimatif, dan e) Kepastian hukum. Ketentuan tersebut menegaskan perlindungan Saksi dan Korban adalah mutlak harus dilakukan, sehingga proses penegakan hukum dapat berjalan dengan baik.

Selanjutnya diatur pula mengenai tujuan dari undang-undang ini yang diatur di dalam pasal 4 yaitu Perlindungan Saksi dan Korban bertujuan memberikan rasa aman kepada saksi dan/korban dalam memberikan keterangan pada setiap proses peradilan pidana. Ketentuan diatas menunjukkan tujuan dari undangundang ini sangat baik, karena saksi dan korban menginginkan rasa aman, 
sehingga mereka dapat memberikan keterangan tanpa harus mengalami rasa takut.

Adapun ketentuan yang lainnya diatur di dalam pasal 5 ayat (1) mengenai hak saksi dan korban sebagaimana diterangkan berikut ini :

Seorang Saksi dan Korban berhak:

a. Memperoleh Perlindungan atas keamanan pribadi, keluarga, dan harta bendanya, serta bebas dari ancaman yang berkenaan dengan kesaksian yang akan, sedang atau telah diberikannya.

b. Ikut serta dalam proses memilih dan menentukan bentuk perlindungan dan dukungan keamanan.

c. Memberikan keterangan tanpa tekanan.

d. Mendapat penerjemah.

e. Bebas dari pertanyaan yang menjerat.

f. Mendapatkan informasi dari perkembangan kasus.

g. Mendapatkan informasi dari Putusan Pengadilan.

h. Mengetahui dalam hal terpidana dibebaskan.

i. Mendapat Identitas baru.

j. Mendapatkan kediaman baru.

k. Memperoleh penggantian biaya transportasi sesuai kebutuhan.

1. Mendapat nasehat hukum, dan/atau

m. Memperoleh bantuan biaya hidup sementara sampai batas waktu perlindungan berakhir.

Ketentuan diatas menunjukkan bahwasanya seorang saksi dan korban berhak memperoleh keamanan erat memperoleh biaya. Dengan kata lain seorang Saksi dan Korban harus benar-benar-benar mendapatkan haknya sebagaimana dari tujuan hukum yang baik itu sendiri.

Pengaturan tentang perlindungan Korban sudah cukup baik, hanya saja undang-undang ini belum dijadikan rujukan bagi penegak hukum terutama Majelis Hakim dalam pertimbangannya terhadap perlindungan Korban seksual.

\section{Perlindungan Korban Seksual Dalam Hukum Pidana Indonesia.}

Usaha mengurangai meningkatnya tindak pidana baik secara kualitas maupun kuantitas, selama ini fokus perhatian hanya tertuju pada upaya-upaya yang bersifat tekhnis, misalnya bagaimana menentukan metode penjatuhan 
86 | TAZKIR: Jurnal Penelitian Ilmu-ilmu Sosial dan Keislaman

Vol. 04 No. 1 Juni 2018

sanksi yang tegas agar menghasilkan efek jera pada pelaku tindak pidana atau mencegah orang untuk melakukan tindak pidana, peningkatan sarana prasarana pendukung dan penambahan anggaran operasional. Akibatnya fokus perhatian pada korban.

Adanya pandangan bahwa korban hanya berperan sebagai instrumen pendukung atau pelengkap dalam pengungkapan kebenaran materil, misalnya ketika korban hanya diposisikan sebagai saksi dalam suatu kasus Pidana, sudah saatnya ditinggalkan. Begitu pula pandangan yang menyebutkan bahwa dengan telah dipidananya pelaku, korban kejahatan sudah cukup memperoleh perlindungan hukum, tidak dapat dipertahankan lagi

Kedudukan korban seakan telah didiskriminasikan oleh hukum pidana, padahal dalam konteks perbuatan hukum pidana, korban pada dasarnya merupakan pihak yang paling dirugikan. Oleh karena itu mulai berkembang pemikiran yang menyuarakan agar orientasi hukum pidana Indonesia yang selama ini yang bersifat Offender oriented, yaitu pelaku tindak pidana merupakan fokus utama dari hukum pidana, agar segera diubah. Perkembangan pemikiran dan perlunya perhatian terhadap korban didasari oleh dua pemikiran. Pertama, pemikiran bahwa negara ikut bersalah dalam terjadinya korban dan selayaknya negara ikut bertanggung jawab dalam bentuk pemberian konpensasi atau restitusi. Kedua, adanya aliran pemikiran baru dalam kriminologi yang meninggalkan pendekatan prositivis kearah kriminologi kritis.

Penggantian kerugian berupa materi (barang atau uang) merupakan salah satu bentuk pemidanaan tertua yang pernah dikenalkan dalam peradaban manusia. Setiap kelompok manusia didunia mengenal ganti kerugian berupa materi, tidak terkecuali di Indonesia. Mulai dari Jerman kerajaan dahulu hingga sekarang, khususnya dilingkungan masyarakat adat, sistim ganti kerugian sebagai salah satu bentuk sistem pemidanaan masih diakui eksistensinya.

Berdasarkan uraian diatas secara garis besar dalam kitab Undangundang hukum Pidana diatur beberapa hak yang dapat digunakan oleh korban kejahatan khususnya pencabulan dalam suatu proses peradilan pidana yaitu:

1. Hak untuk melakukan kontrol terhadap penyidik dan penuntut umum hak ini adalah hak untuk mengajukan keberatan terhadap tindakan penghentian penyidikan dan atau penuntutan dalam kapasitasnya sebagai pihak ketiga yang berkepentingan (pasal 77 jo 80 KUHAP). Hal ini penting 
untuk diberikan guna menghindarkan adanya upaya dari pihak-pihak tertentu dengan berbagai motif yang bermaksud menghentikan proses pemeriksaan.

2. Hak korban berkaitan kedudukannya sebagai saksi.

Hak ini adalah untuk mengundurkan diri sebagai saksi (Pasal 168 KUHAP). Kesaksian (saksi) korban sangat penting untuk diperoleh dalam rangka mencapai suatu kebenaran materil. Oleh karena itu untuk mencegah korban mengundurkan diri sebagai saksi, diperlukan sikap proaktif dari aparat penegak hukum untuk memberikan jaminan keamanan bagi korban dan keluarganya pada saat mengajukan diri sebagai saksi.

3. Hak untuk menuntut ganti rugi akibat suatu tindak pidana/ kejahatan yang menimpa dari korban melalui cara penggabungan perkara perdata dengan perkara pidana (Pasal 98 sampai dengan 101 KUHAP). Hak ini diberikan guna memudahkan korban untuk menuntut ganti rugi pada tersangka/terdakwa. Permintaan penggabungan perkara gugatan ganti rugi hanya dapat diajukan selambat-lambatnya sebelum penuntut umum mengajukan tuntutan pidana, atau jika penuntut umum tidak hadir permintaan tersebut diajukan selambat-lambatnya sebelum hakim menjatuhkan putusan. Penggabungan Gugatan ganti rugi terhadap terdakwa dalam kasus yang didakwakan kepadanya.

4. Hak bagi keluarga korban untuk mengijinkan atau tidak mengijinkan Polisi melakukan autopsi (Pasal 134-136 KUHAP). Mengijinkan atau tidak mengijinkan Polisi untuk melakukan autopsi juga merupakan suatu bentuk perlindungan korban kejahatan, mengingat masalah autopsi ini bagi beberapa kalangan sangat erat kaitannya dengan masalah agama, adat istiadat serta aspek kesusilaan/kesopanan lainnya.

Berkaitan hak Korban untuk mengajukan tuntutan ganti rugi melalui cara penggabungan perkara sebagaimana diatur dalam pasal 98101 KUHAP, pihak-pihak yang berkepentingan perlu memperhatikan beberapa hak yaitu :

1. Kerugian yang terjadi harus ditimbulkan oleh tindak pidana itu sendiri. 
88 | TAZKIR: Jurnal Penelitian Ilmu-ilmu Sosial dan Keislaman

Vol. 04 No. 1 Juni 2018

2. Kerugian yang ditimbulkan oleh tindak pidana atau orang lain yang menderita kerugian (Korban) sebagai akbat langsung dari tindak pidana tersebut.

3. Gugatan ganti kerugian yang diakibatkan tindak pidana tersebut diajukan kepada pelaku tindak pidana (Terdakwa).

4. Tuntutan Ganti kerugian yang diajukan kepada Terdakwa tersebut digabungkan atau diperiksa dan diputus sekaligus bersamaan pada pemeriksaan dan putusan perkara pidana yang didakwakan kepada terdakwa dan dalam bentuk suatu putusan.

Dalam Declaration of Basic Principles of justice for victim of crime and abuse of fower ketentuan huruf A mengenai Victim of crime sub judul Acces to justice and fair treatment butir 4, 5, 6, dan 7 :

1) Korban harus diperlakukan dengan penuh rasa kasihan dan respek untuk martabatnya. Mereka berhak untuk mengakses mekanisme peradilan terhadapnya dan segera memperoleh ganti rugi yang dilegitimasi oleh perundang-undangan dari penderitaan yang didapat.

2) Peradilan dan proses Administrasinya harus dibangun dan dikuatkan untuk keperluan korban memperoleh ganti rugi baik secara prosedur formal maupun informal yang terbaik, adil, dan dapat diterima korban. Korban harus mendapat informasi mengenai hak-haknya dalam meminta mekanisme ganti rugi terus menerus.

3) Tanggung jawab dari proses peradilan untuk kebutuhan korban harus menfasilitasi beberapa hal:

a) Menginformasikan korban mengenai peran dan kesempatannya waktu dan proses penyelesaian kasusnya, khususnya pada kejahatan serius dan dimana memperoleh informasi.

b) Memberi perhatian pada korban untuk dihadirkan dan dipertimbangkan atau didengar secara tepat dalam proses peradilan dimana mempengaruhi kepentingan korban, tanpa syak wasangka terhadap terdakwa dan konsisten dengan peradilan pidana nasional.

c) Menyediakan asistensi atau pendampingan yang pantas bagi korban sepanjang proses hukumnya.

d) Memberi persyaratan yang meminimalkan penderitaan korban, melindungi perivasi korban ketika perlu dan keamanannya 
termasuk keluarganya dan kepentingan dalam kesaksiannya dari intimidasi dan pembalasan dendam.

e) Menghindari penundaan dan penanganan kasus dan eksekusi untuk ketertiban atau menanggung tanggugangan bagi korban.

Hak-hak korban antara lain :

1. Berhak mendapat konpensasi atas penderitaannya, sesuai dengan taraf keterlibatan korban itu sendiri dalam terjadinya kejahatan tersebut.

2. Berhak menolak restitusi untuk kepentingan pembuat korban (tidak mau diberi restitusi karena tidak memerlukannya).

3. Mendapat restitusi/konpensasi untuk ahli warisnya bila korban meninggal dunia karena tindak pidana tersebut.

4. Mendapat pembinaan dan rehabilitasi.

5. Mendapat hak miliknya kembali.

6. Mendapat perlindungan dari ancaman pelaku bila melapor dan menjadi saksi.

7. Mendapatkan bantuan penasehat hukum.

\section{PENUTUP}

Berdasarkan hasil yang ditemukan di atas, maka ketentuan dalam menentukan hak hukum atau perlindungan terhadap korban [erlu ditetapkan. Terlihat bahwa hak-hak korban masih sedikit bila dibandingkan dengan hakhak pelaku tindak pidana. Pertama, hak untuk mendapatkan bantuan hukum tidak diakomodasi bagi korban. Korban harus berhadapan dengan perilaku aparat penegak hukum dan pelaku. Korban seakan-akan sudah diwakili oleh negara dalam hal ini melalui penegar hukum. Kedua, hak korban untuk mengetahui sejauh mana proses peradilan pidana terhadap kasus yang menimpa dirinya. Ketiga, hak korban untuk memperoleh pendampingan dalam mengurangi penderitaan yang dialaminya, baik secara moral, pisikologis, dan sosial. Keempat, hak korban untuk mendapat jaminan keamanan dari tekanan maupun teror pelaku atau keluarganya. Oleh karenanya perlu diterapkan perlindungan hukum yang lebih nyaman bagi para korban, sehingga merasa aman dan nyaman berada di lingkungan tempat tinggalnya. 
90 | TAZKIR: Jurnal Penelitian Ilmu-ilmu Sosial dan Keislaman

Vol. 04 No. 1 Juni 2018

\section{DAFTAR PUSTAKA}

Abdussalam. Victimology. Jakarta: PT IK, 2010.

Ali, Mahrus. Dasar-Dasar Hukum Pidana. Jakarta: Sinar Grafika, 2011.

Arief, Prof Dr Barda Nawawi. Bunga Rampai Kebijakan Hukum Pidana. Bandung: Prenada Media, 2016 https://books.google.co.id/books?id=Clc_DwAAQBAJ.

Atmasasmita, Romli. Kapita selekta hukum pidana dan kriminologi. Bandung: Mandar Maju, 1995.

Dwiati, Ira. "Perlindungan Hukum Terhadap Korban Tindak Pidana Perkosaan Dalam Peradilan Pidana." Tesis, Universitas Diponegoro, 2007. eprints.undip.ac.id/17750/1/Ira_Dwiati_Tesis.pdf.

Gosita, Arif. Masalah perlindungan anak. Jakarta: Akademika Presindo, 1989.

Manan, Abdul. Aspek-aspek pengubah hukum. Jakarta: Kencana, 2012.

Marlina. Peradilan Pidana Anak di Inonesia, Pengembangan Konsep Diversi dan Restorative Justice. Bandung: PT.Refika Aditama, 2009.

Marpaung, Leden. Kejahatan terhadap kesusilaan dan masalah prevensinya. Jakarta: Sinar Grafika, 1996.

Ali, Prof Dr Achmad. Menguak Teori Hukum \& Teori Peradilan dan Teori Peradilan (Judicialprudence), Termasuk Interpretasi Undang-Undang (Legisprudence). Jakarta: Kencana Prenada, 2009. https://books.google.co.id/books?id=NBZNDwAAQBAJ.

Muhammad, Rusli. Hukum acara pidana kontemporer. Bandung: Citra Aditya Bakti, 2007.

Republik Indonesia, dan Kepolisian Republik Indonesia. Pedoman untuk Penyidikan dan Penuntutan Tindak Pidana Traffiking dan Perlindungan Terhadap Korban Selama Proses penegakan Hukum. Jakarta: International Organization for Migrations Mission In Indonesia dan NZAID, 2005.

Zulfa, Eva Achjani. Pergeseran paradigma pemidanaan. Bandung: Lubuk Agung, 2011. 